\title{
PEMBANGUNAN MODEL RESTAURANT MANAGEMENT SYSTEM
}

\author{
Fredy Jingga; Natalia Limantara \\ Information Systems Department, School of Information Systems, Binus University \\ Jl. K.H. Syahdan No. 9, Palmerah, Jakarta Barat 11480 \\ fjingga@binus.edu, nlimantara@binus.edu
}

\begin{abstract}
Model design for Restaurant Management System aims to help in restaurant business process, where Restaurant Management System (RMS) help the waitress and chef could interact each other without paper limitation. This Restaurant Management System Model develop using Agile Methodology and developed based on PHP Programming Langguage. The database management system is using MySQL. This web-based application model will enable the waitress and the chef to interact in realtime, from the time they accept the customer order until the chef could know what to cook and checklist for the waitress wheter the order is fullfill or not, until the cahsier that will calculate the bill and the payment that they accep from the customer.
\end{abstract}

Keywords: Restaurant Management System, PHP, MySQL, bill of material

\begin{abstract}
ABSTRAK
Pembangunan Model Restaurant Management System adalah pembangunan sistem informasi untuk restoran yang bermanfaat untuk membantu dalam proses bisnis, yang terjadi di restoran agar terintegrasi, mulai dari proses penyediaan bahan baku, pembayaran bahan baku, proses pengolahan bahan baku hingga pemesanan makanan oleh pelanggan. Restaurant Management System dikembangkan menggunakan metode agile dan menggunakan bahasa pemrograman PHP. Manajemen data yang ada didalamnya menggunakan My SQL. Model Restaurant Management System ini dibuat berbasis web dengan tujuan untuk memudahkan bagian gudang untuk mengecek persediaan bahan baku dan memesan ke pemasok, pelayan untuk mencatat pesanan pelanggan, kepala chef dapat melihat pesanan yang masuk secara real time dan memberikan tanda untuk makanan yang sudah selesai dimasak, hingga kasir dapat mencatat pembayaran yang diterima dari pelanggan.
\end{abstract}

Kata kunci: Restaurant Management System, PHP, MySQL, bill of material 


\section{PENDAHULUAN}

Dewasa ini, bisnis restoran semakin menjamur. Banyak restoran yang berhasil menarik customer, tetapi banyak pula yang gagal. Faktor penyebabnya selain pangan, yang lebih penting adalah pelayanan (service) yang diberikan. Sistem manajemen restoran yang terintegrasi, atau singkatnya disebut software restoran, akan sangat membantu pihak restoran untuk memberikan layanan yang lebih cepat dan lebih baik kepada customer, pada saat yang sama memberikan kendali yang handal untuk manajemen restoran. Software restoran dapat digunakan untuk menangani keseluruhan operasi restoran, mulai dari saat customer datang, memesan makanan, penyajian makanan, penyediaan material, pencatatan material yang digunakan hingga sampai customer melakukan pembayaran.

Dengan cakupan yang luas dan tingkat kerumitan yang cukup tinggi, salah satu tantangan yang dihadapi oleh pengembang software restoran adalah menyediakan tampilan antar muka (interface) yang mudah dimengerti dan mudah dioperasikan oleh semua staf restoran. Biasanya pada jam-jam sibuk restoran, kesalahan-kesalahan yang sering terjadi yaitu adanya makanan yang dipesan oleh customer lupa diolah di pantry karena kurangnya koordinasi antara head chef dengan chef-chef, adanya makanan yang dimasak tidak sesuai dengan customer's order karena kesalahan dalam menerima informasi oleh waiter/waitress, customer's order diantar ke table yang salah karena waiter/waitress tidak mencatat secara jelas customer's order yang ada, adanya customer yang harus menunggu lama untuk mendapatkan tagihan karena cashier harus mencari tagihan-tagihan dan menghitung tagihan secara manual, cashier lupa menagih pembayaran setelah menerbitkan tagihan karena tidak fokus akibat restoran ramai dan harus mencari serta menghitung tagihan customer. Dengan menggunakan software restoran, seluruh informasi yang dibutuhkan sudah tercatat di sistem, dan dapat diakses di terminal terdekat.

\section{Tinjauan Pustaka}

\section{Pengertian Restaurant}

Berdasarkan Rutherford dan O’Fallon (2010), Restaurant adalah fasilitas yang menyajikan berbagai jenis makanan dan minuman untuk para tamu, yang dirancang untuk kenyamanan para tamu dalam menikmati hidangan.

\section{Pengertian Pembelian}

Menurut Soemarso S.R, (2005), Pembelian (purchasing) adalah akun yang digunakan untuk mencatat semua pembelian barang dagang dalam suatu periode. Sedangkan menurut Bodnar dan Hoopwood, (2004), pembelian merupakan sinonim dari pengadaan, yang diartikan sebagai berikut: "Pengadaan adalah proses bisnis memilih sumber, pemesanan, dan memperoleh barang dan jasa". Dari definisi di atas dapat disimpulkan bahwa, pembelian merupakan kegiatan yang dilakukan untuk pengadaan barang yang dibutuhkan perusahaan dalam menjalankan usahanya dimulai dari pemilihan sumber sampai memperoleh barang.

\section{Pengertian Penjualan}

Menurut Kotler dan Amstrong (2006), Penjualan merupakan sebuah proses di mana kebutuhan pembeli dan kebutuhan penjualan dipenuhi, melalui antar pertukaran informasi dan kepentingan. Menurut Kertajaya, (2006), penjualan adalah bagaimana menciptakan hubungan jangka panjang dengan pelanggan melalui produk atau jasa dari sebuah perusahaan. Dalam hal ini penjualan adalah bagaimana strategi yang akan digunakan untuk mengintegrasikan perusahaan, pelanggan, dan korelasi antar keduanya. Menurut Hollander, (2000, p230), Penjualan adalah serangkaian dari kegiatan operasi yang secara bersama-sama dilakukan untuk menarik pelanggan, membantu pelanggan memilih barang 
dan jasa, menyampaikan barang dan jasa yang dibutuhkan, dan mengumpulkan pembayaran untuk barang dan jasa.

\section{Pengertian Persediaan}

Menurut Alfredson et al., (2006), Persediaan adalah asset yang tersedia untuk dijual dalam proses bisnis biasa atau asset yang ada dalam proses produksi seperti untuk dijual atau asset dalam bentuk material atau supplier untuk digunakan dalam proses produksi atau dalam memberikan pelayanan.

\section{Pengertian Restaurant Management System}

Restaurant Management System adalah teknologi berbasis web yang membantu dalam pengelolaan restaurant. RMS menyediakan wadah yang terintegrasi untuk pengelolaan bahan baku hingga menjadi bahan siap saji di restaurant serta bertindak sebagai pusat pengelolaan restaurant sehingga bisa digunakan oleh pelayan serta chef di restaurant didalam mengelola dan melaksanakan kegiatan operasional di dalam restaurant.

\section{Iterative and Agile System Development Lifecycle}

Agile development adalah sebuah proses pengembangan sistem informasi yang menekankan pada flesibolitas untuk mengantisipasi persyaratan baru selama proses pengembangan sistem. Iterative developement adalah pendekatan pengembangan sistem di mana sistem dibangun bagian per bagian melalui beberapa kali perulangan. Bagian sistem diselesaikan terlebih dahulu kemudian proses diulangi untuk perbaikan dan penambahan hingga semua sistem selesai dibangun. Gambar 1 menjelaskan mengenai aktivitas utama yang harus dilalui jika mengembangkan sebuah sistem informasi menggunakan iterative and agile SDLC.

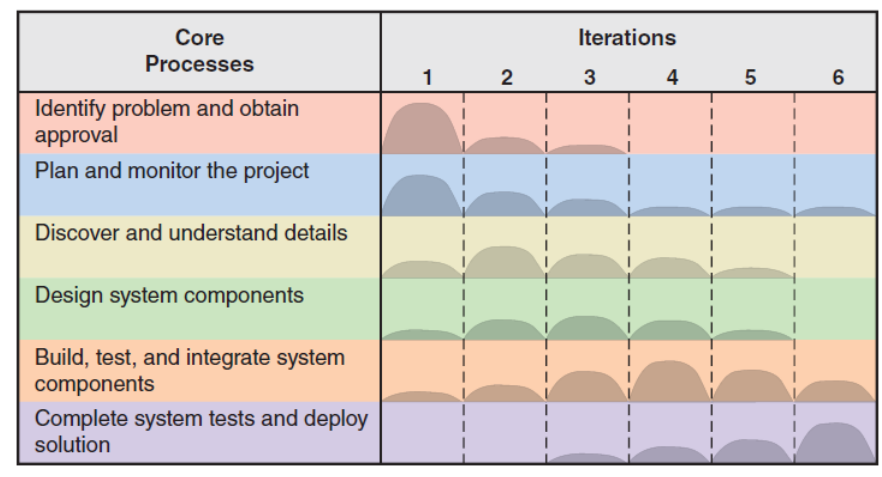

Gambar 1 Iterative and Agile Systems Development Lifecycle (sumber: Satzinger, 2012)

\section{METODE}

Metode yang digunakan dalam penyusunan model Restaurant Management System untuk sekolah adalah metode iterative and agile systems development lifecycle menurut Satzinger (2012) Berdasarkan metodologi ini, dilakukan tahapan identifikasi masalah mengenai aspek pengelolaan restaurant yang akan ditampilkan di dalam Restaurat Management System (RMS), menganalisa detil model yang diperlukan, dan merancang komponen-komponen sistem yang akan dibuat. Pada tahap ini, akan dihasilkan sebuah model yang dapat diterapkan untuk mengembangkan aplikasi terintegrasi Restaurant Management System yang dapat digunakan secara umum oleh restaurant yang yang ada di Indonesia. 


\section{HASIL DAN PEMBAHASAN}

Berdasarkan observasi yang kami lakukan pada beberapa restaurant yang ada di Indonesia , maka model yang dihasilkan mengacu kepada kebutuhan yang harus ada pada penerapan RMS. Dimulai dari pendataan menu yang disediakan oleh sebuah restaurant, hingga ke penggunaan bahan baku yang dipergunakan oleh masing-masing menu untuk mempermudah prediksi bahan baku yang dipergunakan dalam persiapan pesanan dari pelanggan, dan dilanjutkan dengan checklist serta table locker yang dipergunakan untuk mengelola proses bisnis sebuah restaurant, dan juga perhitungan tagihan serta pencatatan pembayaran yang dilakukan oleh pelanggan restaurant. Berdasarkan komponen-komponen tersebut, maka aktivitas yang akan dilakukan dalam RMS ini dapat digambarkan dalam Gambar 2.

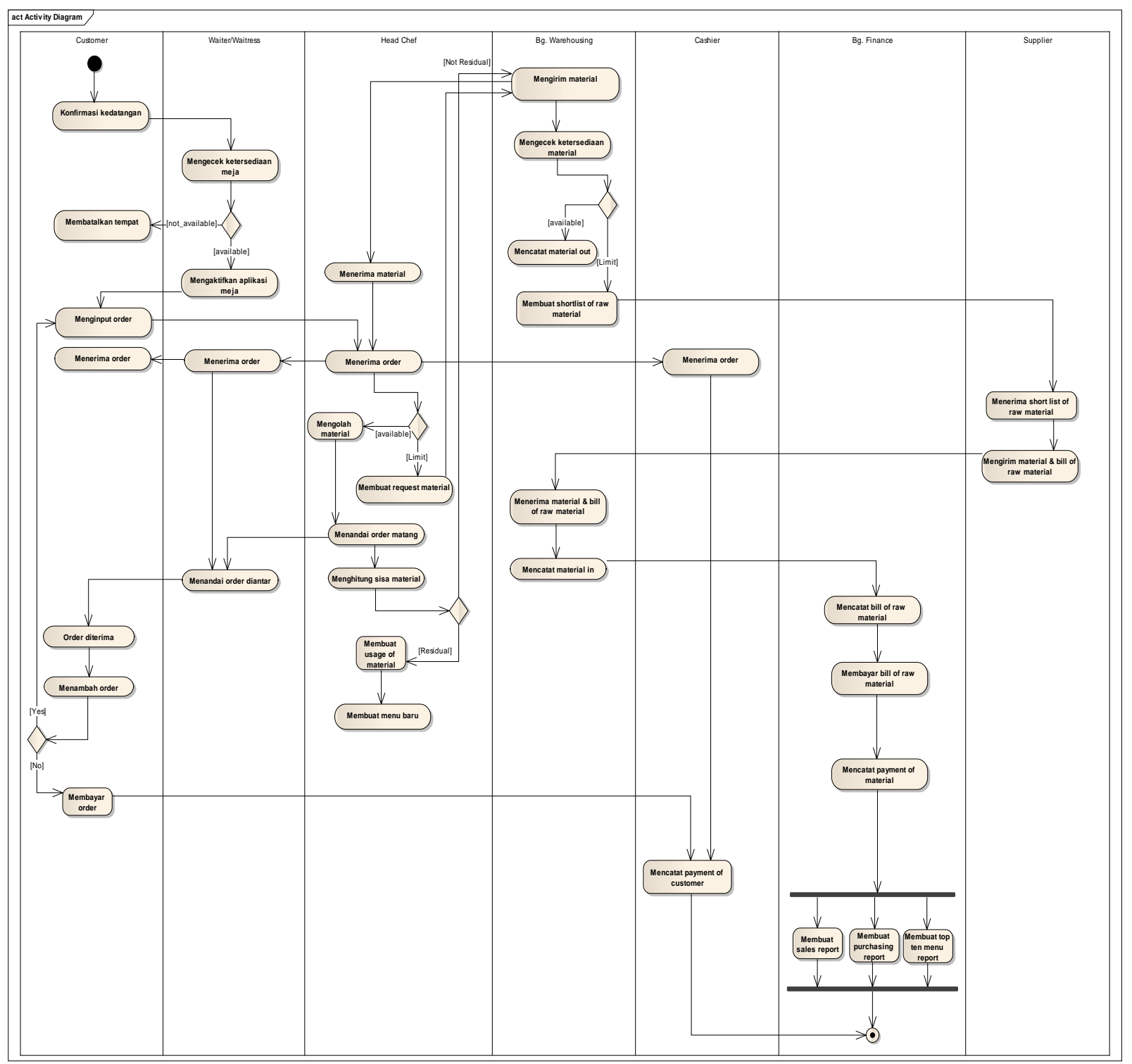

Gambar 2 Activity Diagram untuk Restaurant Management System 
Business Process yang terjadi di RMS ini adalah customer melakukan konfirmasi kedatangan. Maksudnya adalah: (1) Customer datang ke restoran untuk makan di tempat. Kemudian customer diharuskan untuk melakukan konfirmasi ke captain station's table. (2) Customer bisa menelepon untuk mem-booking tempat. Pada saat mem-booking, customer harus memberikan data nama dan phone number-nya yang bisa dihubungi, tanggal dan waktu kedatangan, serta kapasitas orang yang akan datang.

Selanjutnya waiter/waitress akan mengecek ketersediaan tempat. Maksudnya adalah: (1) Untuk customer yang akan makan di tempat pada waktu itu (tanpa booking), maka waiter/waitress akan mengecek ketersediaan tempat dan menyesuaikannya dengan kapasitas orang yang datang pada saat itu juga. Jika ada tempat tersedia maka waiter/waitress akan mengaktifkan aplikasi yang ada di table tersebut, dan mengganti status table menjadi unlock (tidak terkunci) lagi. (2) Apabila customer yang melakukan booking, waiter/waitress juga akan mengecek ketersediaan tempat apakah pada waktu yang diinginkan customer tersebut tersedia tempat yang sesuai dengan kapasitas orang yang akan datang. Jika tempat tidak tersedia untuk kedua kondisi di atas, maka keputusan akan dikembalikan kepada customer. Customer bisa membatalkan tempat, atau menunggu sampai tersedianya tempat yang kosong. Selanjutnya, jika tempat tersedia dan aplikasi di table telah aktif, maka customer dapat meng-input pesanannya.

Di bagian internal restoran, setiap paginya sebelum restoran buka bagian warehousing akan mengirimkan material (bahan baku) yang sesuai dengan aturan perusahaan untuk me-restock material yang ada di pantry. Material yang sudah diterima oleh pantry, head chef akan membuat bill of material yang berisikan material-material yang digunakan untuk membuat menu. Tujuannya adalah untuk melakukan break down material terhadap menu secara real time. Setelah mengirimkan material ke pantry, bagian warehousing akan mengecek ketersediaan material, apabila stock masih banyak maka bagian warehousing akan langsung mencatat material yang dikeluarkan untuk pantry ke dalam material out. Apabila stock-nya sudah terbatas dan mengeluarkan alert system maka bagian warehousing akan membuat daftar belanja material (short list of raw material) ke supplier.

Supplier akan mengirimkan material yang sesuai dengan short list of raw material beserta tagihannya (bill of raw material). Bagian warehousing akan menerima material beserta tagihannya, kemudian material yang diterima akan dicatat dalam form material in dan tagihannya akan diberikan ke bagian finance untuk dicatat dalam bill of raw material. Bagian finance akan membayarkan tagihan tersebut berdasarkan bill of raw material dan mencatatnya dalam payment of material. Material yang diterima oleh pantry dari bagian warehousing akan digunakan untuk mengolah dan menghasilkan menu yang sesuai dengan order dari customer. Order yang telah di-input oleh customer akan masuk ke dalam aplikasi pantry, kemudian head chef akan mengkoordinir para chef untuk memasak menu-menu dari order yang di-input tersebut.

Special Condition: Apabila suatu hari head chef beserta chef nya menemukan suatu inovasi menu hasil olahan dari material, maka head chef dapat mencatatnya ke dalam master menu window. Setelah matang, head chef akan mengganti status order di aplikasi tersebut sebagai tanda bahwa menu telah matang dan diberikan kepada waiter/waitress. Waiter/Waitress akan menerima order yang telah matang dari bagian pantry, kemudian waiter/waitress akan mengantar order ke meja customer dan mengganti status order dalam aplikasi pada table customer sebagai tanda bahwa order telah diterima customer.

Customer yang telah menerima order bisa langsung menyantap makanan yang telah tersedia. Setelah selesai makan, customer bisa menambah order atau langsung membayarkan tagihannya di cashier. Pembayaran yang diterima oleh cashier dari customer akan dicatat ke dalam payment of customer. Setiap periode, bagian finance akan membuat sales report berdasarkan payment of customer, purchasing report berdasarkan payment of material, dan top ten menu report berdasarkan 10 menu yang paling banyak dipesan customer. Dan report-report tersebut akan diberikan kepada pihak management restoran. 


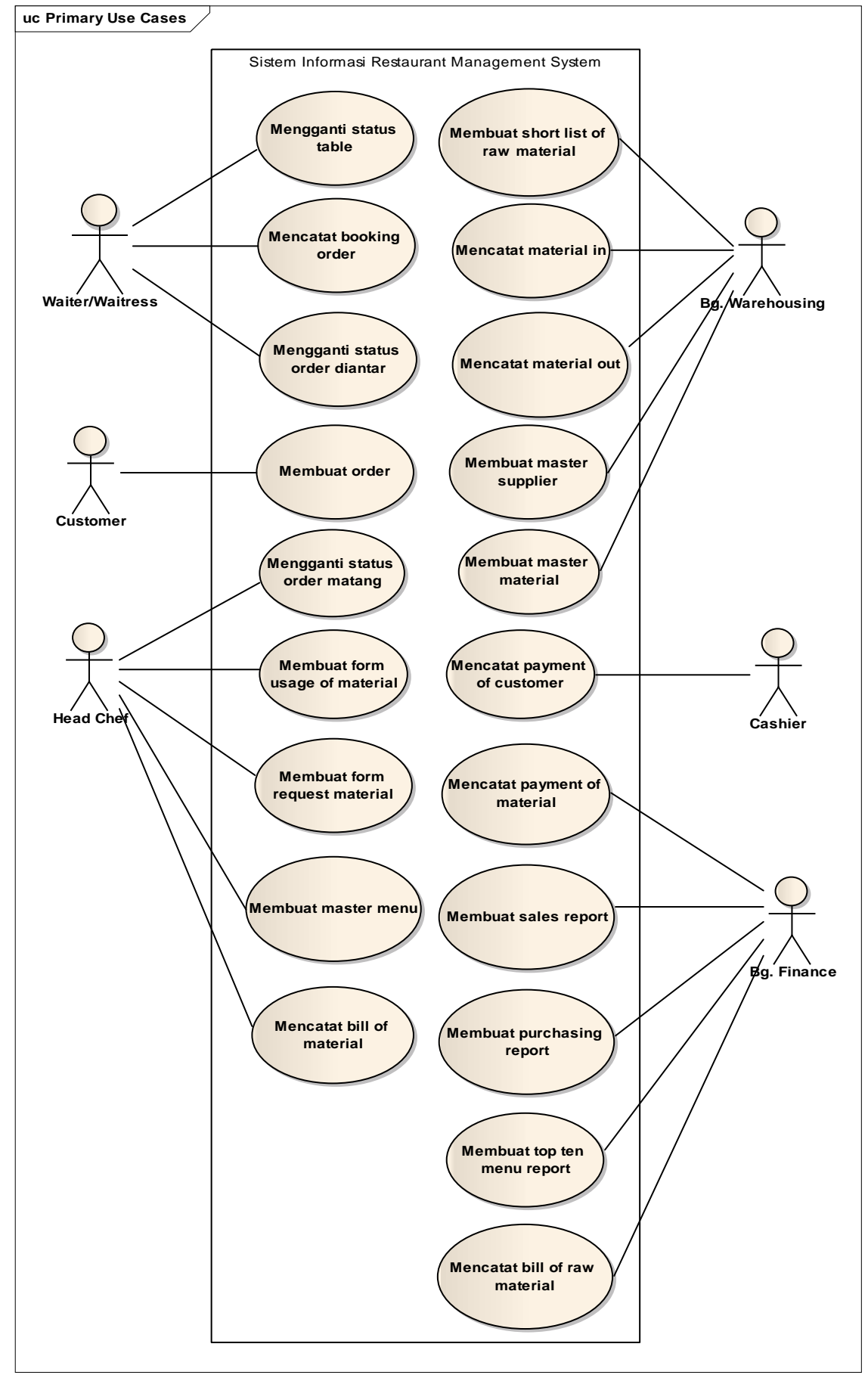

Gambar 3 Use Case Diagram Restaurant Management System

Gambar 3 menerangkan mengenai kegiatan-kegiatan yang akan ditangani oleh Restaurant Management System. Tahapan selanjutnya, perancangan model Restaurant Management System dilanjutkan dengan merancang domain model class diagram yang dapat digunakan untuk pengembangan model Restaurant Management System selanjutnya. Domain model class diagram ini dapat dijadikan landasan dalam tahapan perancangan database yang akan digunakan oleh Restaurant Management System ini. Domain class diagram yang digunakan dalam model Restaurant Management System ini dapat dilihat pada Gambar 4. 


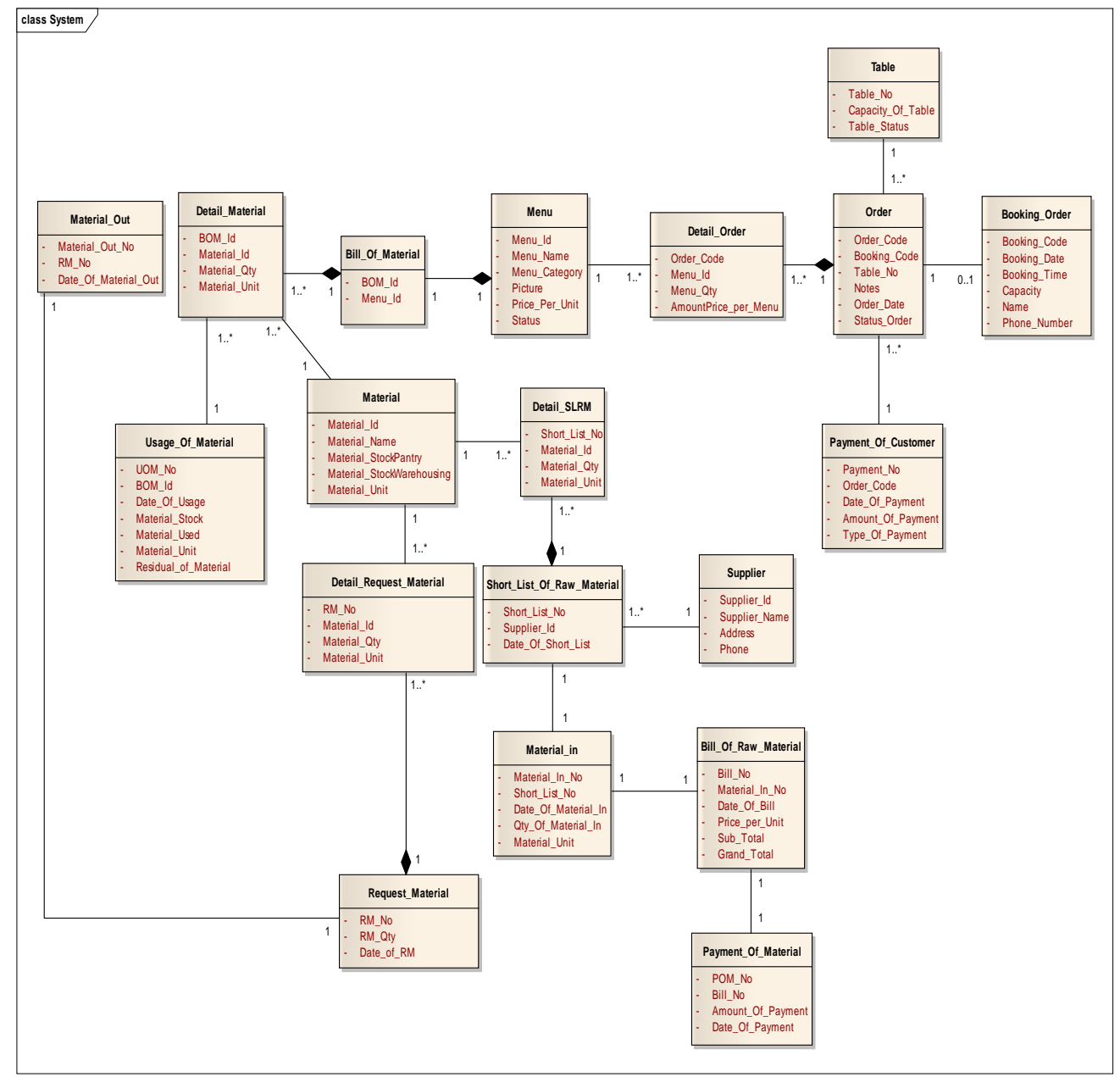

Gambar 4 Domain Class Diagram

Tahapan perancangan model Restaurant Management System untuk sekolah dilanjutkan pada tahapan perancangan user interface. User interface dirancang sesederhana mungkin untuk memudahkan pengguna dalam menggunakan sistem yang disediakan. Gambar 5 menampilkan rancangan layar untuk mendatakan setiap menu yang disediakan oleh restaurant, menu ini akan tampil pada halaman pemilihan menu, sehingga user akan mendatakan beserta dengan gambar yang akan ditampilkan untuk ditunjukkan kepada pelanggan restaurant nantinya.

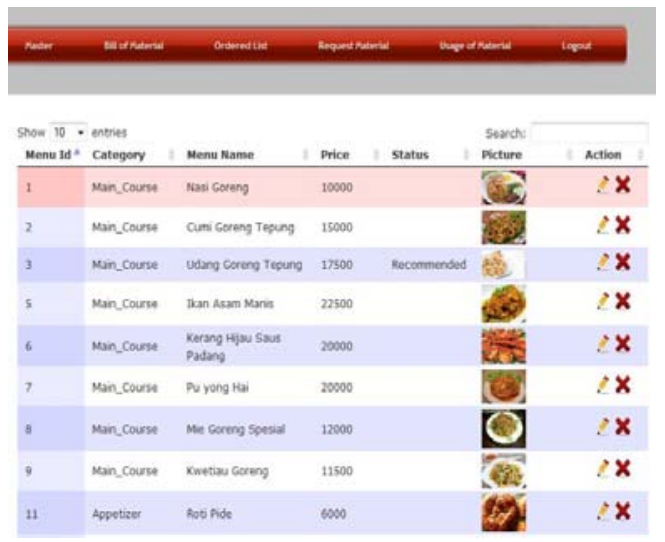

Gambar 5 Rancangan Layar Pendataan Menu 
Head Chef juga dapat mendatakan bahan baku yang digunakan per masing-masing menu yang didatakan di user interface sebelumnya. Hal ini dimaksudkan untuk mempermudah prediksi bagian gudang dalam mempersiapkan bahan baku yang digunakan untuk setiap menu restaurant yang dipesan oleh pelanggan. Tampilan pendataan bahan baku tersebut dapat dilihat pada Gambar 6.

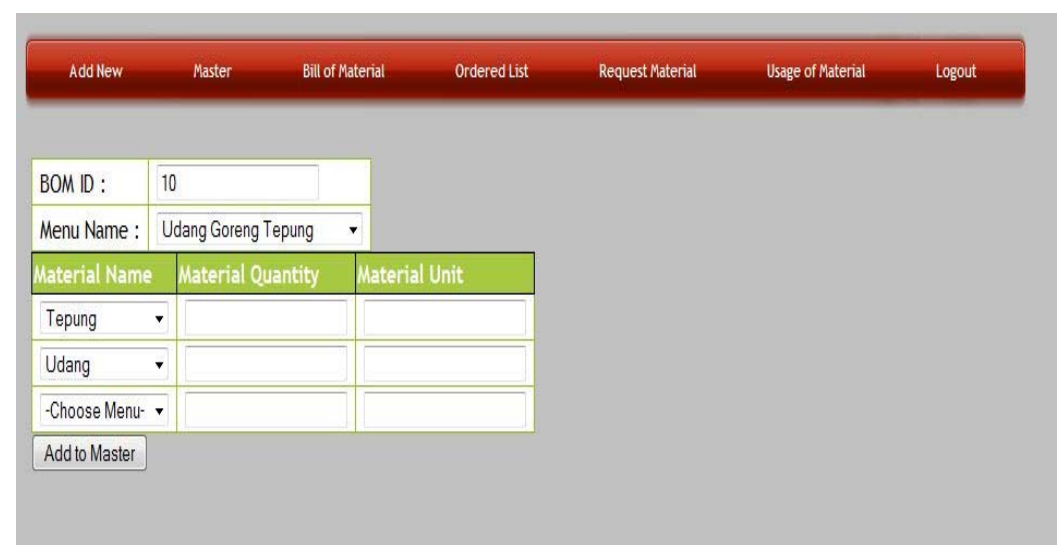

Gambar 6 Rancangan Layar add bill of material

Sebagai kelengkapan pembuatan model Restaurant Management System, Gambar 8 menggambarkan navigation diagram yang mempelihatkan navigasi/perpindahan antar muka yang dibuat untuk Restaurant Management System. Penelitian yang melengkapi didalam penelitian ini telah dilakukan oleh Bora, Paresh R., Gupta, Eshan (2012), di mana mereka membuat Order management system yang bisa membantu customer di dalam memvisualisasikan apa order yang dibuat. Fitur dari hasil penetlitiannya dapat dilihat pada Gambar 7

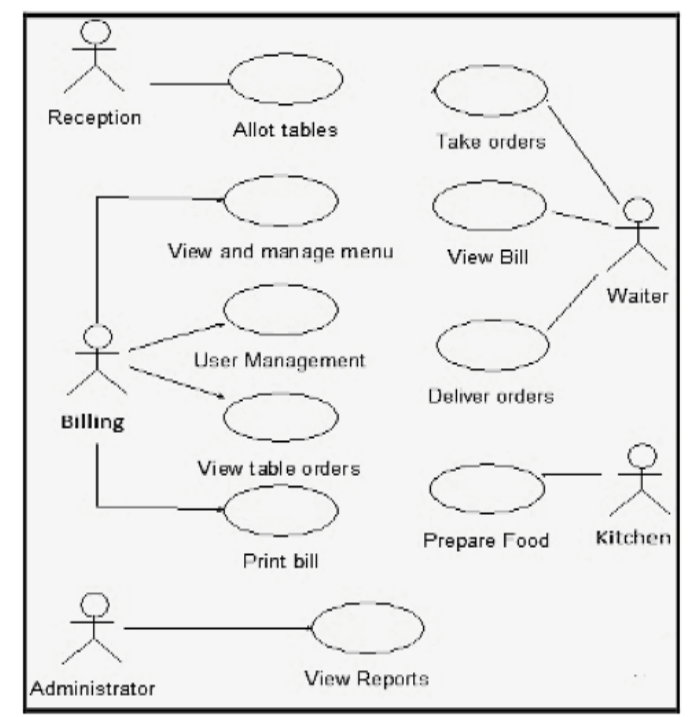

Gambar 7 Fitur Order Management System

Bora, Paresh R., Gupta, Eshan (2012) 


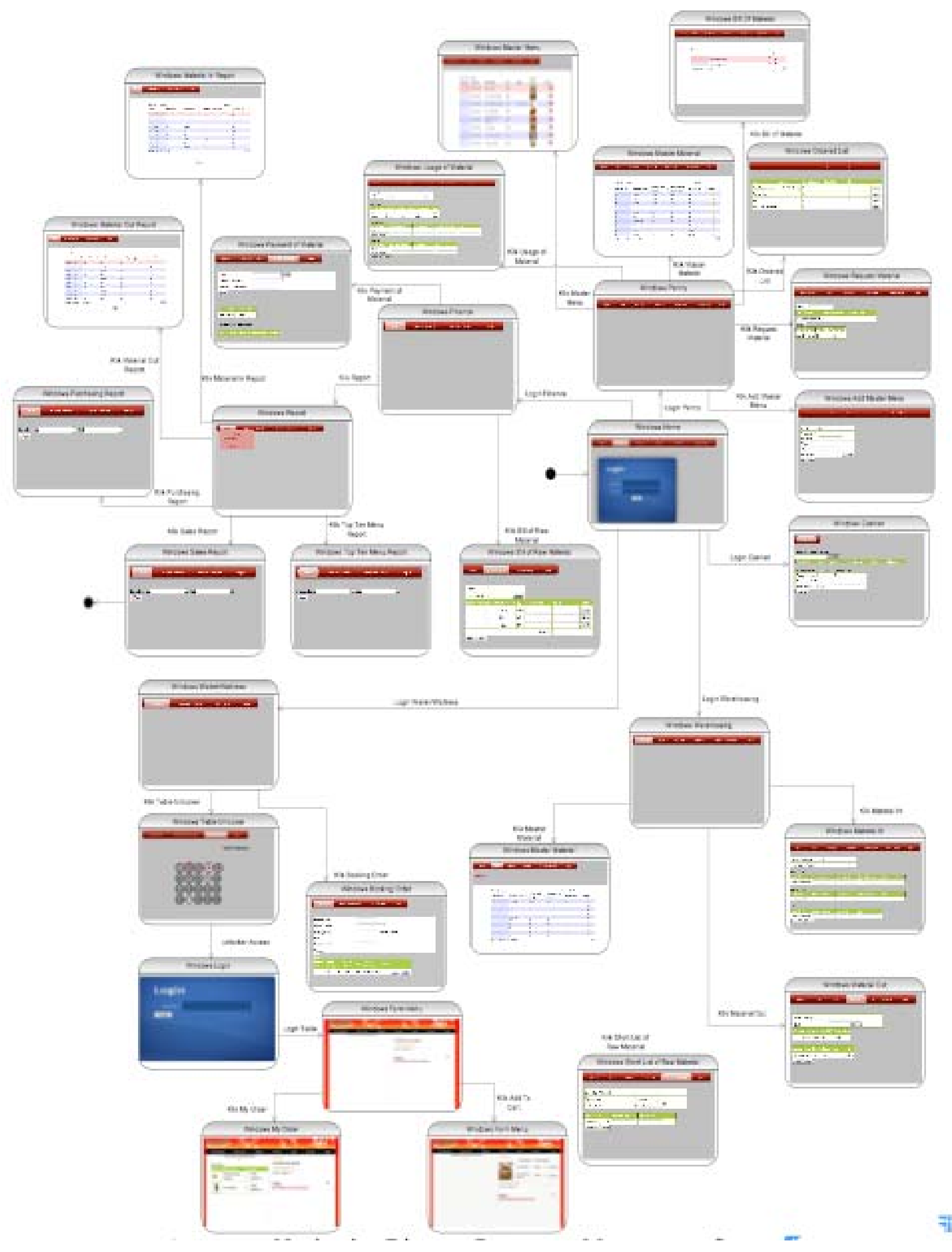

Gambar 8 Navigation Diagram Restaurant Management System 


\section{SIMPULAN}

Dari hasil Pembangunan model Restaurant Management System (RMS), dapat disimpulkan sebagai berikut: (1) Dengan adanya fitur aplikasi order pada table di restoran, maka customer dapat memilih apa yang mereka inginkan dengan lebih bebas, meningkatkan pelayanan customer, dapat mengurangi kesalahan informasi yang disampaikan waiter/waitress ke bagian pantry, dan dapat mengurangi kertas yang digunakan untuk customer's order. (2) Aplikasi Restaurant Management System menyediakan fitur-fitur yang menarik untuk customer's order seperti dapat memesan secara personal pada table masing-masing, adanya detail gambar yang ditampilkan untuk menu yang dipilih, adanya function add to cart untuk dapat menambahkan order yang ingin dipesan, dapat melihat pesanan yang telah di-order dalam fitur my order dan dapat menambah informasi tambahan untuk menu yang ingin dipesan secara khusus. (3) Aplikasi Restaurant Management System ini merupakan sistem yang mendukung dalam pengintegrasian semua proses order menu yang ada pada customer, bagian pantry, waiter/waitress, dan cashier sehingga bagian-bagian terkait dapat segera menindak lanjuti dengan lebih cepat.

\section{DAFTAR PUSTAKA}

Alfredson Keith, Leo Ken, Picker Ruth, Pacter Paul, Radford Jennie Wise Victoria. (2006). Applying International Financial Reporting Standards, Enchanced Edition. Australia: Wiley.

Bodnar, George H. and Hoopwood, William S. (2004). Accounting Information System. (9th Edition). Thomson Course Technology.

Bora, Paresh R., Gupta, Eshan (2012), “APPLICATION ON ORDER MANAGEMENT SYSTEM IN RESTAURANTS”, International Journal of Application or Innovation in Engineering \& Management (IJAIEM), Volume 1, Issue 2, October 2012,p59 - p62

Hollander, Anita Sawyer., Denna, Eric L. and Cherrington, J Owen. (2000). Accounting, Information Technology, and Business Solutions. (2th Edition). McGraw-Hill International Editions.

Kertajaya, Hermawan. (2006). Hermawan Kertajaya on Selling. Jakarta : Mizan.

Kotler, Philip, Amstrong, Gary. (2006). Principles of Marketing. (11th Edition). New Jersey: Pearson Education.

Rutherford, D.G., dan O’Fallon, M.J. (2010). Hotel Managment and Operations. (5th Edition). New Jersey: John Wiley and Sons, Inc.

Satzinger John W., Jackson Robert B., and Burd Stephen D. (2012). Introduction to Systems Analysis and Design: an Agile, Iterative Approach. $6^{\text {th }}$ Edition . COUTE. Canada.

Soemarso S.R. (2005). Akuntansi suatu Pengantar. Edisi Lima. Jakarta: Salemba Empat. 